\title{
Occurrence of 15 Haplotypes of Linepithema micans (Hymenoptera: Formicidae) in Southern Brazil
}

\author{
Manuela Oliveira Ramalho, ${ }^{1,2}$ C. Martins, ${ }^{3}$ T. Campos, ${ }^{1}$ A. Nondillo, ${ }^{4}$ M. Botton, ${ }^{4}$ and \\ O. C. Bueno' ${ }^{1}$
}

1Universidade Estadual Paulista "Júlio de Mesquita Filho" UNESP - Campus Rio Claro, Biologia, CEIS. Av. 24A, 1515, Bela Vista, 13506-900, Rio Claro-SP, Brazil (manuramalho2010@gmail.com; tauanacaipora@gmail.com; odaircb@rc.unesp.br), ${ }^{2}$ Corresponding author, e-mail: manuramalho2010@gmail.com, ${ }^{3}$ Universidade Federal do Piauí - Campus Ministro Reis Velloso, Av. São Sebastião, 2819, 64.202-020, Parnaíba, Piauí, Brazil (martins.c@ufpi.edu.br), and Embrapa Uva e Vinho - Laboratório de Entomologia, Av. Livramento 515, Conceição, 95700-000, Bento Gonçalves - RS, Brazil (alinondillo@gmail.com; marcos.botton@embrapa.br)

Subject Editor: Brad Coates

Received 3 January 2017; Editorial decision 3 May 2017

\begin{abstract}
The ant genus Linepithema is widely known, thanks to the pest species Linepithema humile (Mayr), which is easily mistaken for Linepithema micans (Forel) due to their morphological similarity. Like L. humile, L. micans is associated to the main grapevine pest in Brazil, Eurhizococcus brasiliensis (Wille), also known as ground pearl. Therefore, the present study uses mtDNA fragments to expand the knowledge of haplotype diversity and distribution of L. micans in the state of Rio Grande do Sul (Brazil), to understand the genetic differences of the populations identified in this study. We identified 15 haplotypes of $L$. micans spread across different localities. Twelve of these haplotypes were new for the species. The high haplotype diversity uncovered in Rio Grande do Sul (Brazil) for this species was predictable, as L. micans is in its native environment. Additional studies that take gene flow into account may reveal interesting aspects of diversity in these populations.
\end{abstract}

Key words: mitotype, ground pearl, Rio Grande do Sul

The ant genus Linepithema Mayr is well-known around the world thanks to the Argentine ant, Linepithema humile (Mayr), which is widely distributed and considered invasive and a pest in many countries. Bolton (2016) recognized 20 valid species in this genus, distributed in Central and South America and some countries in Africa, Europe, and Oceania.

For many years, L. humile (Hymenoptera: Formicidae) was considered prevalent and the only species of this genus (Gallotti 1976, Soria and Gallotti 1986, Botton et al. 2010) in areas infested by Eurhizococcus brasiliensis (Wille) (Hemiptera: Margarodidae) that is considered the main grapevine pest in Brazil (Gallotti 1976, Soria and Gallotti 1986, Botton et al. 2010). However, Sacchett et al. (2009) identified many species of ants, including Linepithema micans (Forel 1908), in the vineyards of the Serra Gaucha region that were infested by $E$. brasiliensis. This result was confirmed in the Brazilian state of Rio Grande do Sul by Martins et al. (2012) using molecular techniques. This high visibility of L. humile as the main pest likely stems from the great similarity between the workers of the two species, which causes errors arising from morphology-based identifications (Wild 2007).

The association of E. brasiliensis with L. micans has generated problems for viticulture, especially in southern Brazil (Nondillo et al. 2013, 2016). One of the important aspects of the survival of $E$. brasiliensis is its interaction with ants that harvest the expelled sugar excretions ("honeydew") in a mutualistic association, in which both the ant and hemipteran pests are benefited (Sacchett et al. 2009, Nondillo et al. 2013). A significant increase in the population size of E. brasiliensis and L. micans occurs when they are associated, demonstrating the importance of this ant species in the establishment of the scale on the roots of grapevine plant (Nondillo et al. 2013, 2014, 2016). So far, the use of toxic baits to manage L. micans to reduce vineyard infestation by scales has yielded promising results (Nondillo et al. 2014). However, the ecological interactions of L. micans with E. brasiliensis and its role in their dispersal are not fully known. Understanding the diversity and distribution of this species in its natural environment is essential to properly control ground pearl infestations (see Nondillo et al. 2016). In this sense, it is important to learn how diverse L. micans is in its natural environment, because the systematics of this group is complex (Wild 2007). Furthermore, the ability of $L$. micans to adapt to different conditions and ecological roles may be explained by its close phylogenetic relationship with L. humile (Wild 2009). This raises the possibility that this species may also display eruptive population dynamics in its native environment (Martins et al. 2012).

Sequencing mtDNA fragments is a frequent tool to distinguish different haplotypes and to understand evolutionary processes. Martins et al. (2012) characterized mitochondrial fragments (partial 


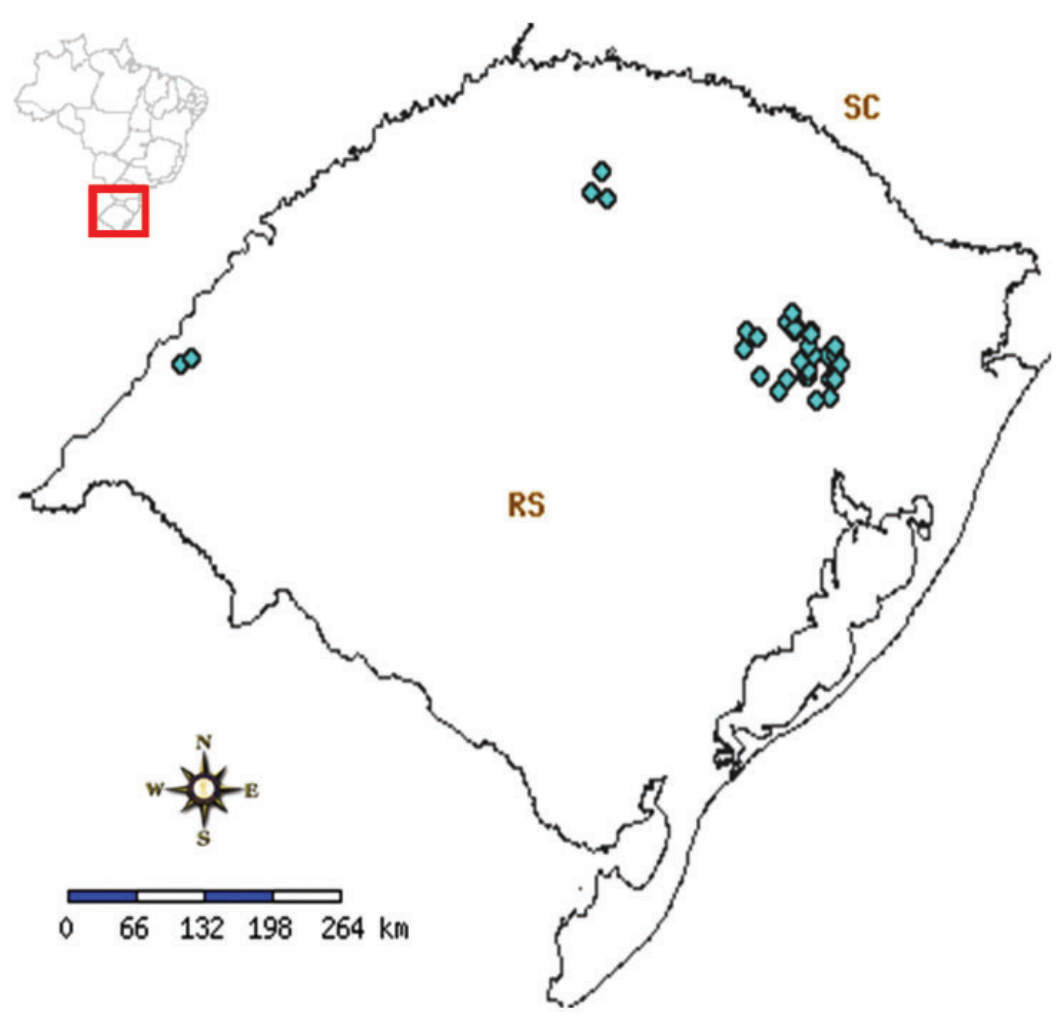

Fig. 1. Collection sites of L. micans for the present study.

COI, tRNAleu, and partial COII) in populations of L. micans in southern Brazil and identified three different haplotypes. The present study aims to expand the knowledge of haplotype diversity and distribution in the region of state of Rio Grande do Sul (Brazil), in an attempt to understand the genetic differences of the populations identified in this study.

\section{Materials and Methods}

\section{Study Areas}

Ants were collected from grapevines that were infested with ground pearl in the following grape-producing municipalities in the state of Rio Grande do Sul, Brazil: Antônio Prado, Caxias do Sul, Dois Lajeados, Farroupilha, Flores da Cunha, Garibaldi, Monte Belo do Sul, Nova Pádua, Pinto Bandeira, Sarandi, and Veranópolis (55 properties in total, Fig. 1).

There were two collections per vineyard block between 2008 and 2011, one in spring/summer and the other in autumn/winter. The ants were collected using underground pitfall traps designed by Morini et al. (2004) with slight modifications. The traps consisted of a set of two empty, black, plastic pipes $(3.3 \mathrm{~cm}$ diameter by $5.0 \mathrm{~cm}$ height) connected by a $5.0-\mathrm{cm}$ string, with a cap and 21 lateral holes $(3 \mathrm{~mm})$. The string was connected to the bottom of the plastic pipe to be able to locate the traps in the soil.

Two kinds of food attractants were used as bait for the ants in the traps. In one of the containers we used cotton wool soaked with a diluted honey solution $(70 \%)$ and in the other, sardines preserved in vegetable oil. The baits were placed inside the lid of each container. The pitfall traps were placed in the soil to a depth of $\sim 20 \mathrm{~cm}$ and were left in the field for a period of $24 \mathrm{~h}$, when they were collected and brought to the laboratory for sorting. After sorting, the ants were stored in vials containing $70 \%$ alcohol to be identified later.

\section{Species Identification}

The ants were separated into morphospecies, and one specimen of each was mounted following the protocol described by Longino (2000). The ants were identified to subfamily (Bolton 2003) and genus (Bolton 1994). Morphological identification was performed in two steps: at the level of morphospecies, by comparison to specimens deposited in the collection of the Alto Tietê Myrmecology Lab at Universidade de Mogi das Cruzes (Brazil), and at the level of species, by Alex Wild (University of Texas/Austin). Linepithema micans was found in 35 of the 55 vineyard blocks sampled; the sampling locations are shown in Fig. 1 and listed in Table 1.

\section{Genetic Analyses}

All the ants collected within each property were treated as a single L. micans population, both because of their territorial behavior, which is unlikely to allow other subtypes of the same species to forage nearby, and because they are polydomous, i.e., they inhabit numerous nests spread over several meters, sometimes even kilometers. Thus, the high incidence of $L$. micans in vineyard makes it impossible to establish other species of ants (Nondillo, personal observation). Therefore, the analysis included 35 populations of L. micans in total. For each population, DNA was extracted from 10 whole individuals, randomly selected. The ants were stored in $80 \%$ alcohol and chilled to $-20^{\circ} \mathrm{C}$ from the date of collection until the extraction. The extractions followed the protocol of Martins et al. (2012).

The GoTaq Hot Start Polymerase kit (Promega) was used for DNA amplification, carried out in a Veriti thermal cycler (Applied Biosystem). The protocol for each amplification reaction was adjusted to $5.0 \mu \mathrm{l}$ GoTaq Flexi Buffer; $1.0 \mu \mathrm{l}$ dNTPs $(2 \mathrm{mM}) ; 2.5 \mu \mathrm{l}$ $\mathrm{MgCl}_{2}(25 \mathrm{mM}) ; 1.5 \mu \mathrm{l}$ forward primer (ANT-F 5'-ATTCATTCTT ATCTTGAAATATTATTTC- $3^{\prime}$ ) and $1.5 \mu \mathrm{l}$ reverse primer (ANT-R 5'-TTCATAAGTTCAGTATCATTGGTG-3') (Martins et al. 2007), 
Table 1. Linepithema micans collection sites for the present study, with their corresponding haplotypes

\begin{tabular}{|c|c|c|c|}
\hline Haplotype & Sequences & Locality & Geographic coordinates \\
\hline \multirow[t]{9}{*}{ H1 } & Dlbedin & Dois Lajeados & $29^{\circ} 01.354^{\prime} \mathrm{S}, 51^{\circ} 50.522^{\prime} \mathrm{W}$ \\
\hline & DIscussel & Dois Lajeados & $28^{\circ} 58.398^{\prime} \mathrm{S}, 51^{\circ} 48.358^{\prime} \mathrm{W}$ \\
\hline & DLdalmas & Dois Lajeados & $28^{\circ} 56.838^{\prime} \mathrm{S}, 51^{\circ} 50.630^{\prime} \mathrm{W}$ \\
\hline & CSdallegrave & Caxias do Sul & $29^{\circ} 17.838^{\prime} \mathrm{S}, 51^{\circ} 13.827^{\prime} \mathrm{W}$ \\
\hline & FCsmiderle & Flores da Cunha & $29^{\circ} 04.505^{\prime} \mathrm{S}, 51^{\circ} 14.246^{\prime} \mathrm{W}$ \\
\hline & MBSbragagnollo & Monte Belo do Sul & $29^{\circ} 09.743^{\prime} \mathrm{S}, 51^{\circ} 38.862^{\prime} \mathrm{W}$ \\
\hline & APlovatel & Antônio Prado & $28^{\circ} 50.729^{\prime} \mathrm{S}, 51^{\circ} 17.713^{\prime} \mathrm{W}$ \\
\hline & Gagostini & Garibaldi & $29^{\circ} 14.811^{\prime} \mathrm{S}, 51^{\circ} 38.334^{\prime} \mathrm{W}$ \\
\hline & HM026683 (Martins et al. 2012) & Bento Gonçalves & $29^{\circ} 09.0^{\prime} \mathrm{S}, 51^{\circ} 31.0^{\prime} \mathrm{W}$ \\
\hline \multirow[t]{4}{*}{$\mathrm{H} 2$} & Dltoni & Dois Lajeados & $28^{\circ} 57.0^{\prime} \mathrm{S}, 51^{\circ} 47.0^{\prime} \mathrm{W}$ \\
\hline & Fmoroni & Farroupilha & $29^{\circ} 07.682^{\prime} \mathrm{S}, 51^{\circ} 24.394^{\prime} \mathrm{W}$ \\
\hline & Vceppo & Veranópolis & $28^{\circ} 57.224^{\prime} \mathrm{S}, 51^{\circ} 31.292^{\prime} \mathrm{W}$ \\
\hline & Vpertile & Veranópolis & $28^{\circ} 58.192^{\prime} \mathrm{S}, 51^{\circ} 29.425^{\prime} \mathrm{W}$ \\
\hline \multirow[t]{3}{*}{ H3 } & PBcomiatto & Pinto Bandeira & $29^{\circ} 07.883^{\prime} \mathrm{S}, 51^{\circ} 27.265^{\prime} \mathrm{W}$ \\
\hline & CSmarchesini & Caxias do Sul & $29^{\circ} 14.923^{\prime} \mathrm{S}, 51^{\circ} 14.376^{\prime} \mathrm{W}$ \\
\hline & APfalavigna & Antônio Prado & $28^{\circ} 52.673^{\prime} \mathrm{S}, 51^{\circ} 13.971^{\prime} \mathrm{W}$ \\
\hline \multirow[t]{4}{*}{$\mathrm{H} 4$} & PBgiovanini & Pinto Bandeira & $29^{\circ} 08.818^{\prime} \mathrm{S}, 51^{\circ} 26.276^{\prime} \mathrm{W}$ \\
\hline & Vtedesco & Veranópolis & $28^{\circ} 57.343^{\prime} \mathrm{S}, 51^{\circ} 31.374^{\prime} \mathrm{W}$ \\
\hline & APfaraon & Antônio Prado & $28^{\circ} 50.277^{\prime} \mathrm{S}, 51^{\circ} 22.928^{\prime} \mathrm{W}$ \\
\hline & NPalessi & Nova Pádua & $29^{\circ} 01.863^{\prime} \mathrm{S}, 51^{\circ} 19.881^{\prime} \mathrm{W}$ \\
\hline \multirow[t]{3}{*}{ H5 } & Spotrich & Sarandi & $27^{\circ} 51.289^{\prime} \mathrm{S}, 53^{\circ} 01.390^{\prime} \mathrm{W}$ \\
\hline & Scótica & Sarandi & $27^{\circ} 53.706^{\prime} \mathrm{S}, 52^{\circ} 58.838^{\prime} \mathrm{W}$ \\
\hline & CStonietto & Caxias do Sul & $29^{\circ} 13.123^{\prime} \mathrm{S}, 51^{\circ} 15.237^{\prime} \mathrm{W}$ \\
\hline \multirow[t]{2}{*}{ H6 } & Scorno & Sarandi & $27^{\circ} 51.943^{\prime} \mathrm{S}, 53^{\circ} 01.199^{\prime} \mathrm{W}$ \\
\hline & HM026685 (Martins et al. 2012) & Pinto Bandeira & $29^{\circ} 07.0^{\prime} \mathrm{S}, 51^{\circ} 26.0^{\prime} \mathrm{W}$ \\
\hline \multirow[t]{3}{*}{ H7 } & CSlklering & Caxias do Sul & $29^{\circ} 14.477^{\prime} \mathrm{S}, 51^{\circ} 14.363^{\prime} \mathrm{W}$ \\
\hline & Csdklering & Caxias do Sul & $29^{\circ} 17.308^{\prime} \mathrm{S}, 51^{\circ} 14.255^{\prime} \mathrm{W}$ \\
\hline & FCmascarello & Flores da Cunha & $28^{\circ} 59.552^{\prime} \mathrm{S}, 51^{\circ} 13.308^{\prime} \mathrm{W}$ \\
\hline H8 & Frobetti & Farroupilha & $29^{\circ} 12.597^{\prime} \mathrm{S}, 51^{\circ} 26.884^{\prime} \mathrm{W}$ \\
\hline \multirow[t]{2}{*}{ H9 } & FCpelizer & Flores da Cunha & $28^{\circ} 57.910^{\prime} \mathrm{S}, 51^{\circ} 13.516^{\prime} \mathrm{W}$ \\
\hline & FCcasagrande & Flores da Cunha & $29^{\circ} 04.766^{\prime} \mathrm{S}, 51^{\circ} 15.051^{\prime} \mathrm{W}$ \\
\hline H10 & FCventurini & Flores da Cunha & $29^{\circ} 01.683^{\prime} \mathrm{S}, 51^{\circ} 12.983^{\prime} \mathrm{W}$ \\
\hline H11 & Vrmazzarollo & Veranópolis & $28^{\circ} 57.122^{\prime} \mathrm{S}, 51^{\circ} 31.559^{\prime} \mathrm{W}$ \\
\hline $\mathrm{H} 12$ & Vmmazzarollo & Veranópolis & $28^{\circ} 58.616^{\prime} \mathrm{S}, 51^{\circ} 30.044^{\prime} \mathrm{W}$ \\
\hline H13 & NPcamana & Nova Pádua & $29^{\circ} 02.885^{\prime} \mathrm{S}, 56^{\circ} 21.191^{\prime} \mathrm{W}$ \\
\hline H14 & NPtatto & Nova Pádua & $29^{\circ} 01.723^{\prime} \mathrm{S}, 51^{\circ} 16.160^{\prime} \mathrm{W}$ \\
\hline H15 & HM026684 (Martins et al. 2012) & Pelotas & $31^{\circ} 44.0^{\prime} \mathrm{S}, 52^{\circ} 19.0^{\prime} \mathrm{W}$ \\
\hline
\end{tabular}

both at 6 pmol; $0.15 \mu$ GoTaq Hot Start; $3.0 \mu \mathrm{l}$ resuspended DNA; and q.s. to $2.5 \mu \mathrm{l}$ with autoclaved Milli-Q water. The program of the thermal cycler was adjusted to $95^{\circ} \mathrm{C}$ for $7 \mathrm{~min}$ (initial denaturation), 35 cycles at $94^{\circ} \mathrm{C}$ for $1.5 \mathrm{~min}, 43^{\circ} \mathrm{C}$ for $2 \mathrm{~min}$, and $70^{\circ} \mathrm{C}$ for $3 \mathrm{~min}$, and a final extension at $65^{\circ} \mathrm{C}$ for $7 \mathrm{~min}$. The results of the amplifications were analyzed in $1 \%$ agarose gel.

For some populations, it was necessary to perform nested PCR because the amount of material generated by the amplification was not enough for sequencing. For this reason, a 1:9 dilution of the first PCR product was used as the template DNA for a second PCR reaction.

The PCR reactions were purified with the GFX PCR DNA kit (GE Healthcare) following the protocol of the manufacturer, quantified using NanoDrop 2000 (Thermo Scientific), and directly sequenced with the BigDye Terminator v3.1 Cycle Sequencing Kit (Applied Biosystems) in an automatic sequencer 3130 Genetic Analyzer (Applied Biosystems) using capillary electrophoresis.

The consensus sequences generated were manually edited with BioEdit (Hall 1999) and aligned using ClustalW (Thompson et al. 1994). After the sequences were confirmed by similarity comparison against the NCBI database, the coding regions (COI and COII) were analyzed separately through the ORF Finder (Open Reading Frame Finder) tool of NCBI (http://www.ncbi.nlm.nih.gov/) to confirm the desired fragment. The tRNA genes were identified using tRNAscanSE 1.21 (Lowe and Eddy 1997). The numbers and positions of the synonymous and nonsynonymous mutations (deletions, substitutions, and insertions) were identified using DAMBE (Xia and Xie 2001). A median-joining haplotype network was constructed with Network 4.5.1.0 (Bandelt et al. 1999). Haplotype ( $h$ ) and nucleotide $(r)$ diversity were estimated with DNAsp v5 (Librado and Rozas 2009).

The geographic coordinates of the colonies were transformed into metric distances using the rgdal routine (Bivand et al. 2013) in $\mathrm{R}$ software (R Core Team 2015). The genetic distances (by nucleotide) between each pair of sequences (Table 2) were calculated using the Kimura 2-parameter model (Kimura 1980) in PAUP 4.0 (Swofford 1993). The correlation between genetic and geographic distances was calculated with the Mantel test using the vegan routine in R (Oksanen et al. 2015).

\section{Results and Discussion}

Thirty-four out of the 35 colonies sampled were successfully sequenced. We obtained a 489-bp consensus sequence, with $150 \mathrm{bp}$ corresponding to COI, $60 \mathrm{bp}$ to leucine tRNA, and $271 \mathrm{bp}$ to COII. 
Table 2. Genetic distances based on paired nucleotide differences among L. micans haplotypes

\begin{tabular}{|c|c|c|c|c|c|c|c|c|c|c|c|c|c|c|c|}
\hline & $\mathrm{H} 1^{a}$ & $\mathrm{H} 2$ & H3 & $\mathrm{H} 4$ & H5 & $\mathrm{H} 6^{a}$ & H7 & H8 & H9 & H10 & H11 & H12 & H13 & H14 & $\mathrm{H} 15^{a}$ \\
\hline $\mathrm{H} 1^{a}$ & $x x x$ & & & & & & & & & & & & & & \\
\hline H2 & 3 & $\mathrm{xxx}$ & & & & & & & & & & & & & \\
\hline H3 & 1 & 4 & $\mathrm{xxx}$ & & & & & & & & & & & & \\
\hline $\mathrm{H} 4$ & 4 & 1 & 5 & $\mathrm{xxx}$ & & & & & & & & & & & \\
\hline H5 & 4 & 3 & 5 & 4 & $\mathrm{xxx}$ & & & & & & & & & & \\
\hline $\mathrm{H} 6^{a}$ & 2 & 1 & 3 & 2 & 2 & $\mathrm{xxx}$ & & & & & & & & & \\
\hline H7 & 1 & 2 & 2 & 3 & 5 & 3 & $\mathrm{xxx}$ & & & & & & & & \\
\hline H8 & 22 & 23 & 22 & 24 & 24 & 22 & 23 & $\mathrm{xxx}$ & & & & & & & \\
\hline H9 & 1 & 4 & 1 & 5 & 5 & 3 & 2 & 22 & $\mathrm{xxx}$ & & & & & & \\
\hline H10 & 3 & 6 & 4 & 7 & 7 & 5 & 4 & 23 & 4 & $\mathrm{xxx}$ & & & & & \\
\hline H11 & 1 & 4 & 2 & 5 & 5 & 3 & 2 & 23 & 2 & 4 & $\mathrm{xxx}$ & & & & \\
\hline H12 & 3 & 2 & 4 & 3 & 3 & 1 & 4 & 21 & 4 & 6 & 4 & $\mathrm{xxx}$ & & & \\
\hline H13 & 3 & 6 & 4 & 7 & 7 & 5 & 4 & 23 & 4 & 2 & 4 & 6 & $\mathrm{xxx}$ & & \\
\hline H14 & 1 & 2 & 2 & 3 & 3 & 1 & 2 & 23 & 2 & 4 & 2 & 2 & 4 & $\mathrm{xxx}$ & \\
\hline $\mathrm{H} 15^{a}$ & 6 & 5 & 7 & 6 & 6 & 4 & 7 & 26 & 7 & 9 & 7 & 5 & 9 & 5 & $\mathrm{xxx}$ \\
\hline
\end{tabular}

${ }^{a}$ Haplotypes previously found by Martins et al. (2012).

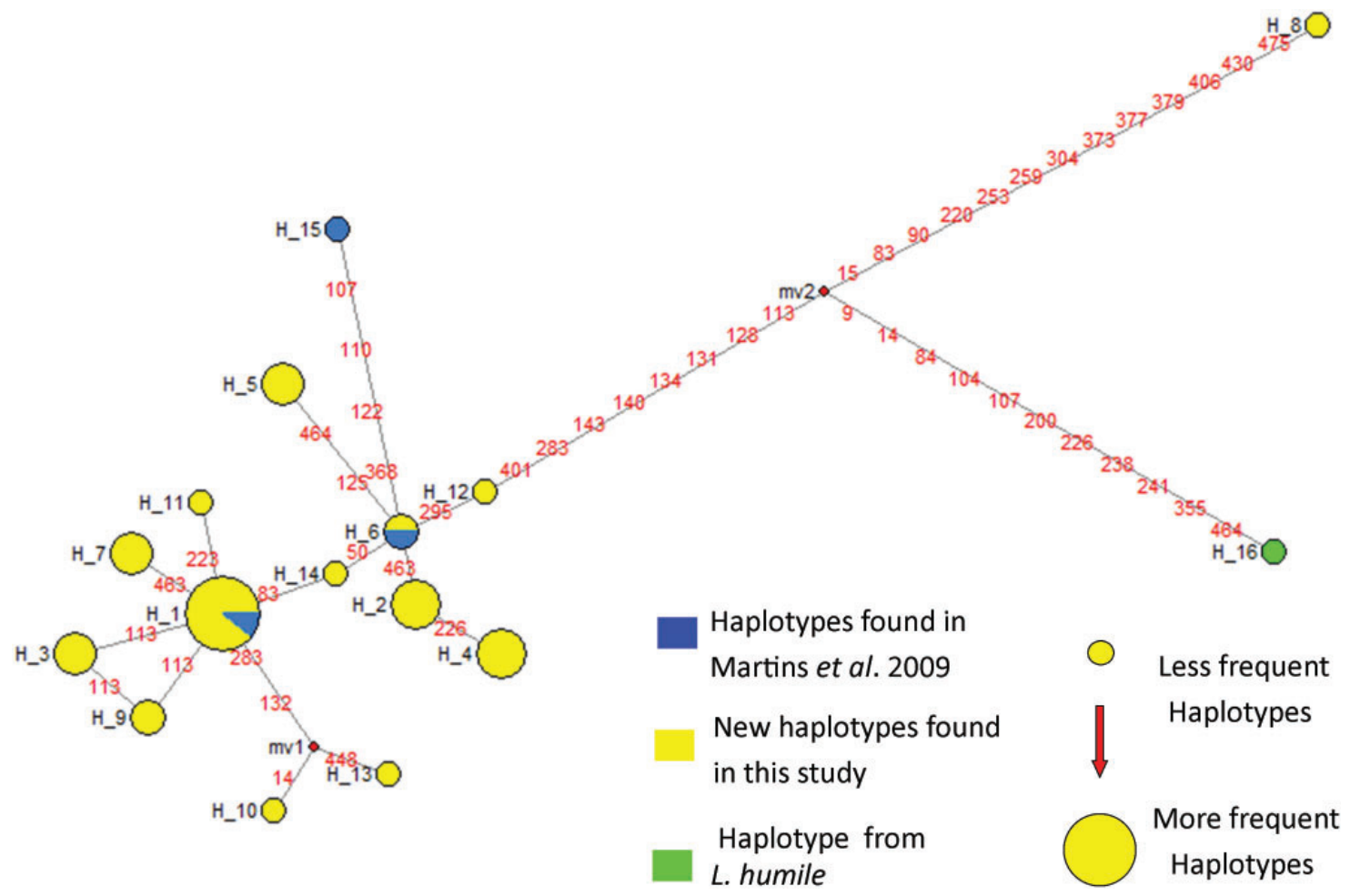

Fig. 2. Linepithema micans haplotype network in Rio Grande do Sul, Brazil. The haplotypes analyzed by Martins et al. (2012) are indicated in blue, and the haplotypes found in this study are indicated in yellow. Linepithema humile haplotype (retrieved from GenBank AF147050) used as outgroup is indicated in green. The haplotype size represent the frequency found, and red numbers represent the sites where there are nucleotide differences between haplotypes. The MV1 point in red was added by the program as hypothetical haplotype.

Nucleotide frequencies were 0.374 for A, 0.143 for C, 0.075 for G, and 0.426 for $\mathrm{T}$, corroborating the high $\mathrm{A}+\mathrm{T}$ frequency for insects (Simon et al. 1994). All samples were distributed into 15 distinct haplotypes; of these, 12 were new for the species. The new findings were deposited in GenBank under accession numbers KM211952KM211965. For comparison, the haplotypes from Martins et al. (2012) were also added to the analyses. The leucine tRNA was identical to the one described by Martins et al. (2012) for L. micans. No variation was found among the additional colonies analyzed, therefore this gene is conserved in this species.

\section{Haplotype Network}

A network analysis identified $15 \mathrm{~L}$. micans haplotypes in Rio Grande do Sul, Brazil (Fig. 2; Table 2). Note how all haplotypes of L. micans are distinct from L. humile. We identified 12 new haplotypes in the present study. H1 and H6 were detected at multiple locations. The H1 haplotype, which had already been found in Bento Gonçalves (Martins et al. 2012), was detected in Dois Lajeados, Caxias do Sul, Flores da Cunha, Monte Belo do Sul, Antônio Prado, and Garibaldi. The H6 haplotype, previously found in Pinto Bandeira (Martins et al. 2012), now has an additional record in 
Sarandi. In contrast, H15 is still confined to Pelotas, as previously observed by Martins et al. (2012). There is no relationship between haplotype variation and geographic location, because haplotypes were shared among different localities. It is also interesting to note that H8, from Farroupilha, was genetically very distant from the other haplotypes. Despite being very different from the others, H8 cannot be considered a separate species, because the delimitation of this species is too complex to be analyzed using a single gene (Green 1996), but we cannot exclude the possibility. Recent studies have adopted the so-called integrative taxonomy approach (Schlick-Steiner et al. 2010, Darienko et al. 2015), which consists of analyses that include more genes (e.g. nuclear genes) and behavioral, natural, and morphological data, among others, to confirm the hypothesis.

Based on genetic distance measured by nucleotide differences, the most variable haplotype $(5.31 \%)$ is $\mathrm{H} 8$, from the Farroupilha colony (Table 2). With the exception of $\mathrm{H} 8$, the maximum difference between pairs of all the other haplotypes was $1.86 \%$, which is an expected value for intraspecific diversity of L. micans (Hebert et al. 2003). The nucleotide differences between haplotypes H1, H6, and $\mathrm{H} 15$ were also analyzed, because these had already been identified by Martins et al. (2012). These haplotypes had the same rate of variation as the others.

Moreover, there is no correlation between the genetic distances and the geographic locations of the colonies using the Mantel test $(r=0.007, P=0.206)$. The lack of correlation may be related to the presence of different ant mitotypes in the neighboring locations. The common association of $L$. micans with grapevines (Sacchett et al. 2009) could explain this widespread distribution, because seedlings of this plant are sold throughout the state, which may facilitate the dispersal of this species to new locations.

The high haplotype diversity observed in Rio Grande do Sul, Brazil ( $\mathrm{h}=0.905$, or 0.911 after excluding H8), was expected for $L$. micans, because this species was in its native environment (Tsutsui et al. 2001). Hence, we believe that the great diversity confirmed by the present study reflects the fact that the species is native to the region. This also gives L. micans the ability to settle in the vineyard, and does not allow other species of ants to associate in the region. More studies that take gene flow into account may reveal interesting aspects of diversity in these populations.

\section{Acknowledgments}

We thank Alex Wild for the morphological identification of specimens. We thank the reviewers and the editor for valuable suggestions that have contributed to the manuscript and the CAPES Foundation for the financial support (process 007343/2014-00), and the Conselho Nacional de Desenvolvimento Científico e Tecnológico (CNPq) and FAPERGS (Fundação de Amparo à Pesquisa do Estado do Rio Grande do Sul).

\section{References Cited}

Bandelt, H. J., P. Forster, and A. Röhl. 1999. Median-joining networks for inferring intraspecific phylogenies. Mol Biol Evol. 16: 37-48.

Bivand, R., T. Keitt, and B. Rowlingson. 2013. rgdal: Bindings for the Geospatial Data Abstraction Library. R package version 0.8-11.

Bolton, B. 1994. Identification guide to the ant genera of the world. Harvard University Press, Cambridge, p. 222.

Bolton, B. 2003. Synopsis ant classification of Formicidae. The American Entomological Institute, Florida, p. 370.

Bolton, B. 2016. An online catalog of the ants of the world. (http://antcat.org) (accessed 3 November 2016).
Botton, M., I. Teixeira, A. Bavaresco, and P. L. Pastori. 2010. Use of soil insecticides to control the Brazilian ground pearl in vineyards. Rev. Col. Entomol. 36: 20-24.

Darienko, T., L. Gustavs, A. Eggert, W. Wolf, and T. Pröschold. 2015. Evaluating the species boundaries of green microalgae (Coccomyxa, Trebouxiophyceae, Chlorophyta) using integrative taxonomy and DNA barcoding with further implications for the species identification in environmental samples. PloS ONE 10: e0127838. doi: 10.1371/ journal.pone. 0127838

Gallotti, B. J. 1976. Contribuição para o estudo da biologia e para o controle químico do Eurbizococcus brasiliensis (Hempel, 1922). Master Thesis, Universidade Federal do Paraná, Curitiba, Brasil, p 63.

Green, D. M. 1996. The bounds of species: hybridization in the Bufo americanus group of North American toads. Israel J. Zool. 42: 95-109.

Hall, T. A. 1999. BioEdit: A user-friendly biological sequence alignment editor and analysis program for Windows 95/98/NT. Nucl. Acids Symp. Ser. 41: 95-98.

Hebert, P. D., A. Cywinska, and A. L. Ball. 2003. Biological identifications through DNA barcodes. Proc. R. Soc Lond B Biol. 270: 313-321.

Kimura, M. 1980. A simple method for estimating evolutionary rates of base substitutions through comparative studies of nucleotide sequences. J. Mol. Evol. 16: 111-120.

Librado, P., and J. Rozas. 2009. DnaSP v5: a software for comprehensive analysis of DNA polymorphism data. Bioinformatics 25: 1451-1452.

Longino, J. 2000. What to do with the data, pp 186-203. In: D Agosti, J. D. Majer, L. E. Alonso, and T. R. Schultz (eds.), Ants: standard methods for measuring and monitoring biodiversity. Smithsonian Institution, Washington, DC.

Lowe, T. M., and S. R. Eddy. 1997. tRNAscan-SE: a program for improved detection of transfer RNA genes in genomic sequence. Nucleic Acids Res. 25: 955-964.

Martins, J., S. E. Solomon, A. S. Mikheyev, U. G. Muller, A. Ortiz, and M. Jr. Bacci. 2007. Nuclear mitochondrial-like sequences in ants: evidence from Atta cephalotes (Formicidae: Attini). Insect Mol. Biol. 16: 777-784.

Martins, C., A. Nondillo, V. G. Martins, M. Botton, and O. C. Bueno. 2012. Occurrence of three haplotypes of Linepithema micans (Forel) (Hymenoptera: Formicidae) in southern Brazil. Neotrop. Entomol. 41: 57-61.

Morini, M.S.C., M. Yashima, F. Y. Zene, R. R. Silva, and B. Jahyny. 2004. Observations on the Acanthostichus quadratus (Hymenoptera: Formicidae: Cerapachyinae) visiting underground bait and fruits of the Syagrus romanzoffiana, in an area of the Atlantic Forest, Brazil. Sociobiology 43: 573-578.

Nondillo, A., V.M.A. Sganzerla, O. C. Bueno, and M. Botton. 2013. Interaction between Linepithema micans (Hymenoptera: Formicidae) and Eurhizococcus brasiliensis (Hemiptera: Margarodidae) in Vineyards. Environ. Entomol. 42: 460-466.

Nondillo, A., C. C. Chaves, F. B. Fialho, O. C. Bueno, and M. Botton. 2014. Evaluation of insecticides for the control of Linepithema micans (Hymenoptera: Formicidae). J. Econ. Entomol. 107: 215-222.

Nondillo, A., S. Andzeiewski, F. B. Fialho, O. C. Bueno, and M. Botton. 2016. Control of Linepithema micans (Hymenoptera: Formicidae) and Eurhizococcus brasiliensis (Hemiptera: Margarodidae) in Vineyards Using Toxic Baits. J. Econ. Entomol. 109: 1660-1666. doi: 10.1093/jee/ tow127Nondillo et al 2016

Oksanen, J., F. G. Blanchet, R. Kindt, P. Legendre, P. R. Minchin, R. B. O’Hara, G. L. Simpson, P. Solymos, M. H. H. Stevens, and H. Wagner. 2015. vegan: Community Ecology Package. R package version 2.3-0.

R Core Team 2015. R: A Language and Environment for Statistical Computing. R Foundation for Statistical Computing, Vienna, Austria.

Sacchett, F., M. Botton, and E. Diehl. 2009. Ants species associated with the dispersal of Eurhizococcus brasiliensis (Hempel in Wille) (Hemiptera: Margarodidae) in Vineyards of the Serra Gaúcha, Rio Grande do Sul, Brazil. Sociobiology 54: 943-954.

Schlick-Steiner, B. C., F. M. Steiner, B. Seifert, C. Stauffer, E. Christian, and R. H. Crozier. 2010. Integrative taxonomy: A multisource approach to exploring biodiversity. Annu. Rev. Entomol. 55: 421-438.

Simon, C., F. Frati, A. Beckenbach, B. Crespi, H. Liu, and P. Flook. 1994. Evolution, weighting, and phylogenetic utility of mitochondrial gene 
sequences and a compilation of conserved polymerase chain reaction primers. Ann. Entomol. Soc. Am. 87: 651-701.

Soria, S.J.V., and B. J. Gallotti. 1986. O margarodes da videira Eurhizococcus brasiliensis (Homoptera: Margarodidae): biologia, ecologia e controle no sul do Brasil. EMBRAPA/CNPUV, Bento Gonçalves, p 22.

Swofford, D. L. 1993. PAUP: Phylogenetic analysis using parsimony. Illinois Natural History Survey, Champaign, IL.

Thompson, J. D., D. G., Higgins, and T. J. Gibson. 1994. ClustalW: improving the sensitivity of progressive multiple sequence alignment through sequence weighting, position specific gaps penalties and weight matrix choice. Nuclelic Acids Res. 22: 4673-4680.
Tsutsui, N. D., A. V. Suarez, D. A. Holway, and T. J. Case. 2001. Relationships among native and introduced populations of the Argentine ant (Linepithema humile) and the source of introduced populations. Mol Ecol. 10: 2151-2161.

Wild, A. L. 2007. Taxonomic revision of the ant genus Linepithema (Hymenoptera: Formicidae). University of California Press, Los Angeles, pp. 159.

Wild, A. L. 2009. Evolution of the Neotropical ant genus Linepithema. Syst. Entomol. Oxford 34: 49-62.

Xia, X., and Z. Xie. 2001. DAMBE: Software package for data analysis in molecular biology and evolution. J. Hered. 92: 371-373. 